\title{
Can We Always Rely on Computed Tomography Perfusion İmaging When Selecting Stroke Patients for Thrombectomy?
}

\section{Trombektomi Için Inmeli Hastalarını Seçerken Her Zaman Bilgisayarlı Tomografi Perfüzyon Görüntülemesine Güvenebilir miyiz?}

İngilizce Kısa Başlık: Reliability of CRP in stroke patients?

Türkçe Kısa Başlık: Inme Hastalarnda BT Perfüzyonun Güvenli mi?

Fergane Memmedova, Semra Arı Sevingil, Fatma Altuntaş Kaya, Ozlem Aykac, Atilla Ozcan Ozdemir

Eskişehir Osmangazi University Faculty Of Medicine Hospital, Department Of Neurology, Eskişehir, Turkey

\section{Corresponding Author Information}

Uzm. Dr. Fergane Memmedova drfergane@gmail.com 05346799629

https://orcid.org/0000-0003-3021-1688

09.06 .2021

17.01.2022

\section{ABSTRACT}

Multimodal görüntüleme yöntemlerinden, perfüzyon bilgisayarlı tomografilerin kullanımı (BTP), son dönemlerde inme merkezlerinde endovaskülar tedavi adaylarını belirlemede önemli araç haline gelmiştir. Bununla birlikte, BTP'nin enfarktüs çekirdeğini tanımlamadaki güvenirliliği, semptom başlangıç zamanına, kollateral durumuna ve diğer klinik faktörlere bağlı olarak değişebilmektedir. Yapılan bazı çalışmalarda, endovasküler tedavi için hasta seçiminde, BTP görüntüleme ile penumbrayı göstermenin tedavide başarı şansını arttırdığ gösterilmiştir. Beyin parankiminde farklı alanların (beyaz cevher, gri cevher gibi) hipoksiye duyarlılığının farklı olması, iskemik doku cevabını belirlemeyi güçleştirmektedir ve bu da perfüzyon çalışmalarının önemini arttırmaktadır. Bu nedenle özellikle son zamanlarda BTP görüntüleme ile çok sayda otomatik yazılım programları kullanılmaya başlanmıştır. Bunlardan RAPID (IschemaView, Menlo Park, California, USA) ve Olea Sphere (Olea Medical Solutions, La Ciotat, France) en sık kullanılanlar arasında siralanmaktadır. Bu programların her birinin enfarkt korunu gösterme oranları, yanılma olasılıkları farklı çalışmalarca ele alınmıştır.

Bu makalede sağ orta serebral arter kliniği ile gelen, uyanma inmesi, 55 yaşında kadın hastanın endovasküler tedavi kararı öncesi yapılan BTP görüntülemelerinin tedavi sürecinde ne kadar yol gösterici olduğunu değerlendirmeyi amaçladık.

Anahtar Kelimeler: Iskemik inme, RAPID, Olea

ÖZ

The use of perfusion computed tomography (CTP), one of the multimodal imaging 
modalities, has recently become an important tool in determining endovascular treatment candidates in stroke centers. However, the reliability of CTP in identifying the infarct core may vary depending on the time of symptom onset, collateral status, and other clinical factors. In some studies, it has been determined that showing the penumbra with CTP imaging increases the chance of success in the selection of patients for endovascular treatment. The difference in sensitivity to hypoxia in the brain parenchyma (such as white matter, gray matter) makes it difficult to determine the ischemic tissue response, thus increasing the importance of perfusion studies. Therefore, many automatic software programs have been used with CTP imaging. Of these, RAPID (IschemaView, Menlo Park, California, USA) and Olea Sphere (Olea Medical Solutions, La Ciotat, France) are among the most frequently used. The rates of each of these programs showing the infarct core and the probability of error discussed by different studies.

In this article, we aime to evaluate the role of CTP imaging in the treatment process before the decision for endovascular treatment of a 55-year-old female patient who presented with right middle cerebral artery clinic and had a wake-up stroke.

Keywords: Stroke, RAPID, Olea

\section{INTRODUCTION}

The use of Computed Tomography Perfusion imaging in the early diagnosis and treatment algorithm of acute ischemic stroke patients has become widespread with the introduction of the third generation computed tomography (CT) (1). CTPs have a large number of automatic software programs. Although their cost, it has been reported that the software programs frequently used in stroke centers are RAPID (IschemaView, Menlo Park, California, USA) and Olea Sphere (Olea Medical Solutions, La Ciotat, France) (2).

CTP is a method based on the examination of brain perfusion using contrast material. By repeatedly imaging a certain part or all of the cerebral parenchyma, the passage of contrast material from arteries to venous structures via capillaries is visualized. From the dynamic images taken after the contrast material; Evaluation is made by forming peak time (TTP), cerebral blood volume (CBV), cerebral blood flow (CBF) maps. TTP indicates the time when the contrast agent reaches the tissue. It is the most sensitive indicator of cerebral ischemia. TTP value increases in these areas because the contrast material is delayed in reaching the ischemic tissue compared to normal tissues. Alternatively, the mean transit time (MTT) or maximum transit time (Tmax) is calculated. Since MTT shows the time between the transfer of the contrast agent into the tissue and its removal from the tissue, it is expected to be prolonged in ischemic areas. This value can be calculated with the formula $\mathrm{MTT}=\mathrm{CBV} / \mathrm{CBF}$. Tmax time increases in ischemic tissue. Although this parameter is widely used, its physiological meaning is not fully understood. Cerebral blood volume (CBV) refers to the volume of blood present in a given brain area at a given moment and is calculated from the area under the time curve. Cerebral blood flow (CBF) shows the blood supply to the brain at a certain time $(1,3)$.

The main purpose of CTP imaging is to determine the ratio of irreversible infarct core area to the penumbra. The penumbra area is the tissue outside the ischemic core that maintains the vitality when reperfusion is achieved. Peripheral of the penumbra area are the less hypoperfused area; the area of benign oligemia. This area maintains its vitality even if reperfusion does not occur. Many different approaches have been present to estimate CTP and penumbra. Areas where CBV is significantly reduced indicate ischemic core, while areas where only $\mathrm{CBF}$ and TTP are reduced indicate penumbra. In summary, the areas where CBV and $\mathrm{CBF}$ incompatibility is observed can be named as the penumbra $(1,2,3)$. In this article, we 
evaluated the role of CT perfusion in the diagnosis and treatment of acute ischemic stroke by comparing the results of RAPID and Olea software.

\section{CASE}

A 55-year-old female patient presented to the emergency department with left-sided weakness and it was evaluated as stroke. CTP was taken because of waking stroke. In his medical history, she had myocardial infarction and cardiac thrombus when she was 40 years old. Transthoracic echocardiography (ECHO) revealed an ejection fraction (EF) of $25 \%$. Although, the patient was followed up with acetylsalicylic acid and beta-blockers in long-term treatment. In her neurological examination at the emergency room, she was conscious, partially cooperative, partially oriented, and speech was mildly dysarthric. The eyes were deviated to the right, PIR: ++/++, left gaze was limited. She had 2/5 hemiparesis, including the left side face and left-sided neglect. The National Institutes of Health Stroke Scale (NIHSS) were evaluated as 18. There were frequent ventricular extrasystoles on electrocardiography, but the basal rhythm was sinus. Although there was no history of stroke in her history, computed tomography (CT) showed chronic infarct areas in the left opercular area and the right frontal cortex, and hyperdense appearance in the right middle cerebral artery (MCA) (Figure 1A). On CT angiography (CTA), the right MCA was observed to be occluded after the level where the anterior temporal artery was spared. (Figure 1B,C). In RAPID, CBF was less than $30 \% 0 \mathrm{~mL}$, mismatch volume $86 \mathrm{ml}$, Tmax $>6.0$-volume $86 \mathrm{ml}$, total Tmax $>6.0$ volume $164 \mathrm{ml}$, total mismatch was $164 \mathrm{~mL}$ (Figure 2), in OLEA the infarct volume was $19.32 \mathrm{cc}$, and the hypoperfused area was $79.22 \mathrm{cc}$ mismatch volume was $59.9 \mathrm{cc}$ (Figure 3). The patient was taken to angiography. With the isolated stent technique, modified Thrombolysis in Cerebral Infarction score was 3 (Figure 4,5). After the procedure, the patient's motor deficit increased to $4 / 5$ hemiparesis. In DWI MR (Diffusion-Weighted Imaging Magnetic Resonance) taken at the 12th hour, infarct areas were observed at the level of the interna capsule and corona radiata on the right. According to $\mathrm{ABC} / 2$ calculation, the infarct volume measured in DWI MR was $2.8 \mathrm{~mL}$ (Figure 6).

In the 24th hour transthoracic Echo, EF of $25.5 \%$, apical akinesia, aneurysmal dilatation, a smear-like organized thrombus and non-ischemic cardiomyopathy were observed. After the patient was transferred to the stroke unit, heparin infusion was started. Warfarin treatment was continued after $48 \mathrm{~h}$. The patient, who was stable during the hospital follow-up period, had a Modified Rankin Scale (mRS) 1 at discharge. In the outpatient follow-up, the third-month mRS was 0 .

\section{DISCUSSION}

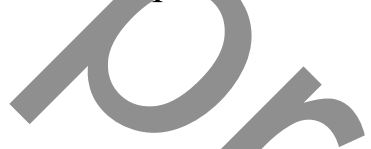

Nowadays, with the development of electronic engineering, the chance of success in the diagnosis and treatment of diseases increases in the field of medicine as in many other fields. Among these diagnostic methods, radiological imaging is important. With the introduction of the third generation CT devices, neurologists' chances of success in the diagnosis and treatment of acute ischemic stroke patients are increasing day by day. Especially in patients with acute ischemic stroke with large vessel occlusion, in making decisions for thrombolytic therapy and mechanical thrombectomy, except the symptom time of the stroke, it is important to evaluate the infarct core area, penumbra and collateral level.

Today, many stroke centers use CTP imaging to bring clarity to these issues $(1,4,5)$. Different automatic software programs were created because of the frequent use of CTP imaging in acute ischemic stroke patients with large vessel occlusion. The most commonly used of these programs is the RAPID software. In the last 1-2 years, the use of the Olea automatic software has become widespread $(4,5)$. In our stroke center, we perform the diagnosis and treatment 
process of stroke patients by using these two software programs within multimodal imaging examinations.

There are studies evaluating how collateral circulation status are related to certain predefined cerebral perfusion parameters using CTP software programs and evaluating their capacity to predict the growth of infarct volume in patients with acute ischemic stroke who are suitable for endovascular therapy (4). Simultaneously, the success rate in the selection of patients who will undergo thrombectomy with these software programs has been investigated $(5,6,7,8,9)$. Even if full recanalization has been achieved in patients, it is important to determine the clear boundaries of ischemic core tissue that has no healing potential (5). Recently, the error rates of CTP imaging have been discussed with increasing software programs. Studies have shown that the estimated volume of infarct in the control DWI MR images taken in the early $24-48 \mathrm{~h}$ of conservatively treated patients is not more than predicted. Additionally, head movement during imaging, errors in the way the contrast agent is administered and its timing can affect the result $(2,3)$. In a prospective study, while the software error rate was $4.7 \%$ with RAPID, this rate was $0.78 \%$ with Olea. Compared to Olea, the ischemic core volume in RAPID is closer to the DWI-MRI infarct volume (2).

Automated computed tomography perfusion is recommended suitability for selection of stroke patients for thrombectomy $>6$ hours from the ictus. However, artifacts on automated perfusion output may overestimate the tissue at risk leading to misclassification of thrombectomy suitability in some patients. In a retrospective study of RAPID data from 410 stroke patients with acute anterior eirculation large vessel occlusion, the mean artifact volume was shown to be $12 \mathrm{cc}$. Although CTP images were reliably described by trained evaluators, of these, $43 \%$ had Tmax $>6$ seconds abnormalities discordant with clinical symptoms and vessel imaging (12).

In this study, the infarct volume (CBF) in RAPID was $0 \mathrm{~mL}$, the infarct volume in Olea was $19.32 \mathrm{cc}$, and the volume in the hypoperfused area was $79.22 \mathrm{cc}$. The total infarct volume was $2.8 \mathrm{~mL}$ on diffusion-weighted imaging taken at the early 12 th hour after TICI3 recanalization was achieved.

In the study by Kurz et al., the sensitivity of RAPID in acute ischemic stroke patients was $40.5 \%$, its specificity was $97.6 \%$, these rates for Olea; sensitivity was shown as $73.7 \%$ and specificity as $68.3 \%$ (3). It has also been shown that RAPID has a numerically higher failure rate than Olea in detecting ischemic brain regions. In another study, it was stated that Olea enlarged the infarct volume by $69.7 \%$ and underestimated the infarct volume by $7.3 \%$. In the use of RAPID, on the other hand, the reduction of infarct volume of $1.7 \%$, enlargement, and incompatibility in infarct volume in $61 \%$ was reported (13).

In conclusion; we wanted to highlight the advantages and limitations of two CTP software programs commonly used in the clinical setting. Discussions about the necessity of CTP in making treatment decisions are still ongoing. Therefore, it is beneficial to use combined multimodal imaging techniques in the diagnosis and treatment of acute ischemic stroke patients with large vessel occlusion by expert neurologists.

\section{Ethics}

Informed Consent: Written and verbal consent was obtained from the patients and their relatives, after informing them.

Authorship Contributions: Interventional Angio and Medical Practices: A.O.O, O.A, F.M, F.A.K. Concept: A.O.O, O.A, F.M. Design: A.O.O, O.A, F.M. Data Collection or Processing: F.M, O.A. Analysis or Interpretation: A.O.O, O.A. Literature Search F.M, O.A. Posted by F.M. Translation: S.A.S.

Conflict of Interest: The authors declared no conflict of interest regarding this article.

Financial Support: No financial support was received from any institution or person for our study. 


\section{REFERENCES}

1. Eraslan C, Çallı C. Akut İskemik İnme: MR ve BT Perfüzyon. Turkiye Klinikleri J RadiolSpecial Topics 2017;10(1):49-55.

2. Xiong Y, Huang Ch.C, Fisher M. M. Comparison of Automated CT Perfusion Softwares in Evaluation of Acute Ischemic Stroke. Journal of Stroke and Cerebrovascular Diseases. 2019;28(12)104392. https://doi.org/10.1016/j.jstrokecerebrovasdis.

3. Kurz KD, Ringstad G, Odland A. etal. Radiological imaging in acute ischaemic stroke: European Journal of Neurology 2015;23(1):8-17. https://doi.org/10.1111/ene.12849. 4. Arenillas J.F, Cortijo E, Garc1'a-Bermejo P. etal. Relative cerebral blood volume is associated with collateral status and infarct growth in stroke patients in SWIFT PRIME. Journal of Cerebral Blood Flow \& Metabolism2017: 0(00) 1-9. https://doi.org/10.1177/0271678X17740293.

5. Mokin M, Levy E.I, Saver J.L. Predictive Value of RAPID Assessed Perfusion Thresholds on Final Infarct Volume in SWIFT PRIME (Solitaire With the Intention for Thrombectomy as Primary Endovascular Treatment). Stroke. 2017; 48:932-938. https://doi.org/10.1161/STROKEAHA.116.015472.

6. Rava R.A, Kenneth V Snyder K.V, Mokin M et al. Assessment of computed tomography perfusion software in predicting spatial location and volume of infarct in acute ischemic stroke patients: a comparison of Sphere, Vitrea, and RAPID. J NeuroIntervent Surg 2020;(0):1-7. http://dx.doi.org/10.1136/neurintsurg-2020-015966.

7. Phipps M.S.,Cronin C.A. Management of acute ischemic stroke. BMJ 2020;368:16983. https://doi.org/10.1136/bmj.16983 (Published 13 February 2020)

8. Albers GW, Marks MP, Kemp S, et al, DEFUSE 3 Investigators. Thrombectomy for Stroke at 6 to 16 Hours with Selection by Perfusion Imaging. N Engl J Med 2018;378:708-18. https://doi: 10.1056/NEJMoa1713973.

9. Albers G.W. Use of Imaging to Select Patients for Late Window Endovascular Therapy. Stroke. 2018;49:2256-2260. https://doi.org/10.1161/STROKEAHA.118.021011.

10. Cereda CW, Christensen S, Campbell BCV, et al. A benchmarking tool to evaluate computer tomography perfusion infarct core predictions against a DWI standard. Blood Flow Metab 2016;36:1780-1789.

11. Hoving JW, Marquering HA, Majoie C, et al. Volumetric and spatial accuracy of computed tomography perfusion estimated ischemic core volume in patients with acute ischemic stroke. Stroke 2018;49:2368-2375.

https://doi.org/10.1161/STROKEAHA.118.020846.

12. Siegler J.E, Olsen A, Pulst-Korenberg J, Cristancho D, Rosenberg J, Raab L, Cucchiara B, Messe S.R. Multicenter Volumetric Assessment of Artifactual Hypoperfusion Patterns using Automated CT Perfusion Imaging. J Neuroimaging 2019;00:1-7. https://doi:

10.1111/jon.12641.

13. Rosenbaum-Halevi D,Vahidy F.S, Daileda T. Et al. Abstract TP61: Determinants of CT Perfusion Misrepresentation of Ischemic Core in Endovascular Stroke Therapy. Stroke. 22 Jan 2018. https://doi.org/10.1161/str.49.suppl_1.TP61 


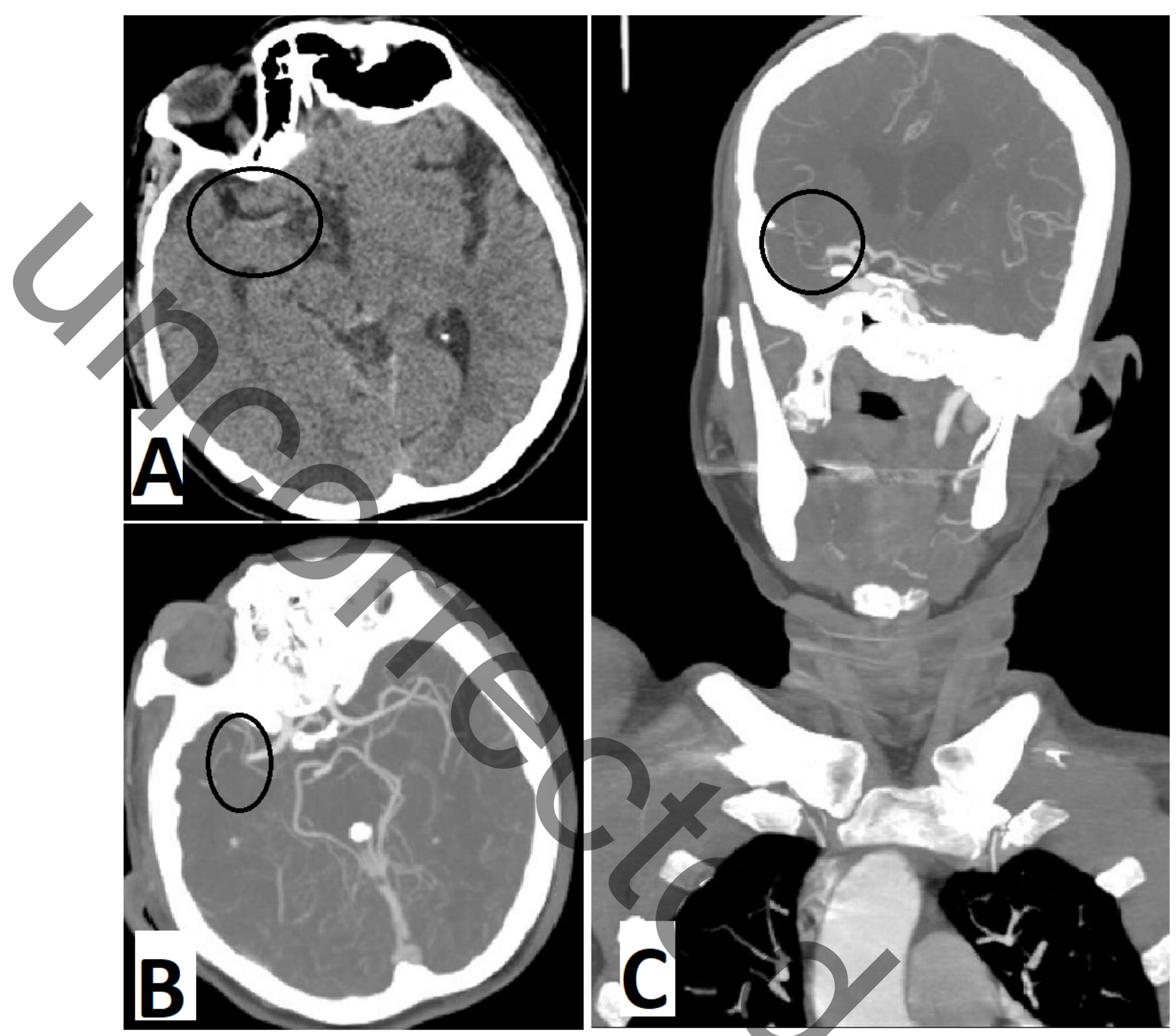

Figure $1 \mathrm{~A})$ Non-contrast $\mathrm{CT}$ imaging of the patient: Hyperdense artery sign in the right middle cerebral artery. Figure 1B) (axial image) and 1C) (Coronal image) CT Angiography; The right MCA was observed to be occluded after the level where the anter

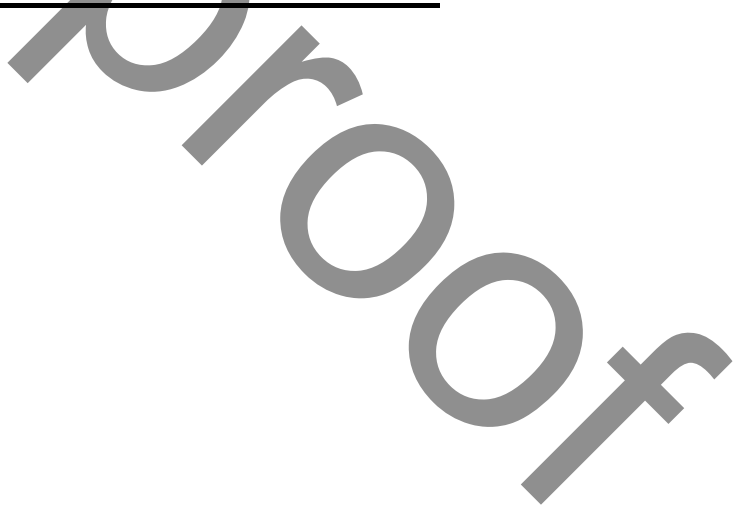




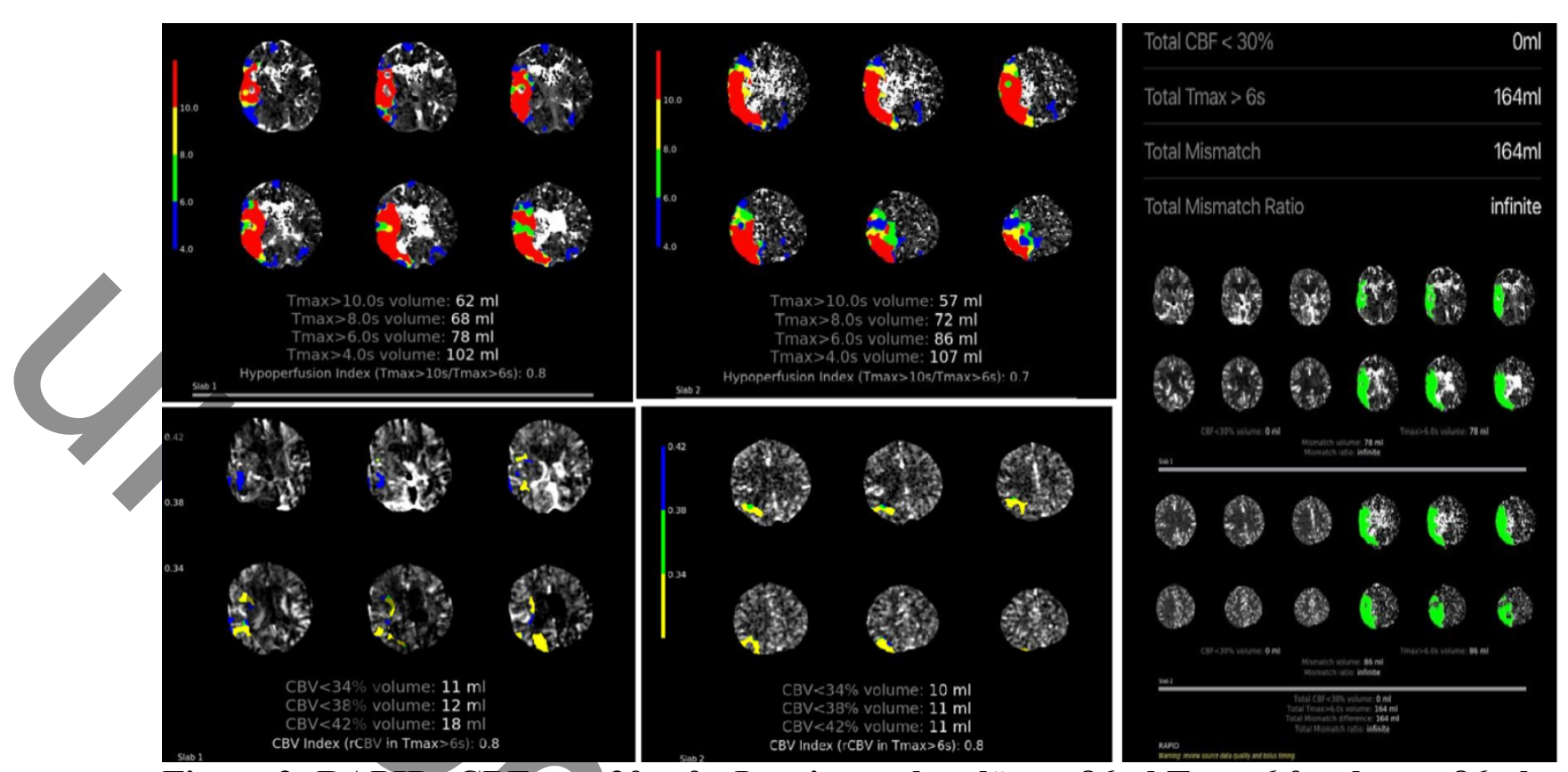

Figure 2: RAPID; CBF was 30_: 0mL, mismatch volüme: $86 \mathrm{ml}$, Tmax6.0 volume: $86 \mathrm{ml}$, total Tmax6.0 volume: $164 \mathrm{ml}$, total mismatch: $164 \mathrm{~mL}$.

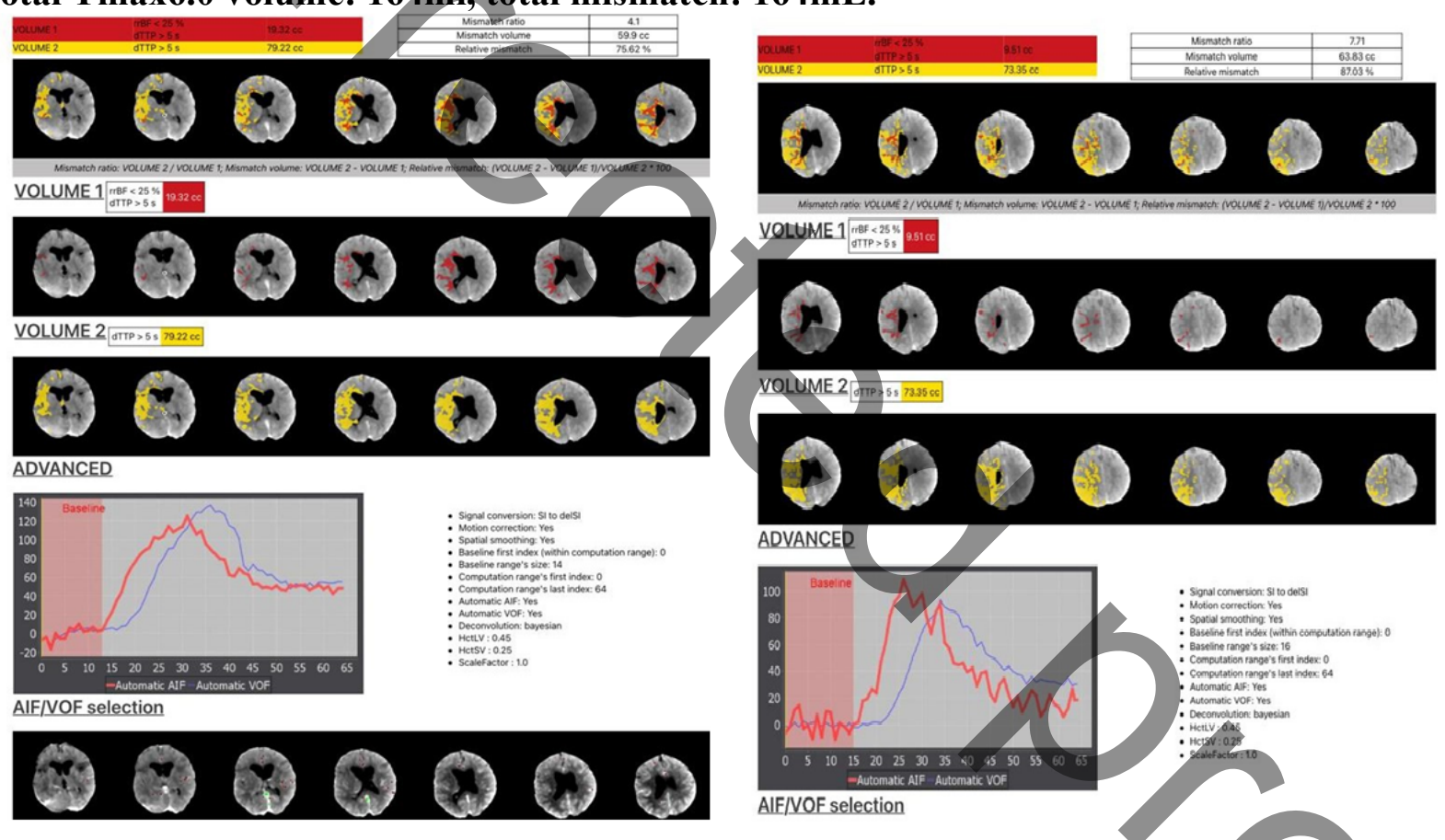

Figure 3: Olea; Volume of the infarct $19.32 \mathrm{cc}$, hypoperfused area $79.22 \mathrm{cc}$,mismatch volume $59.9 \mathrm{cc}$ 


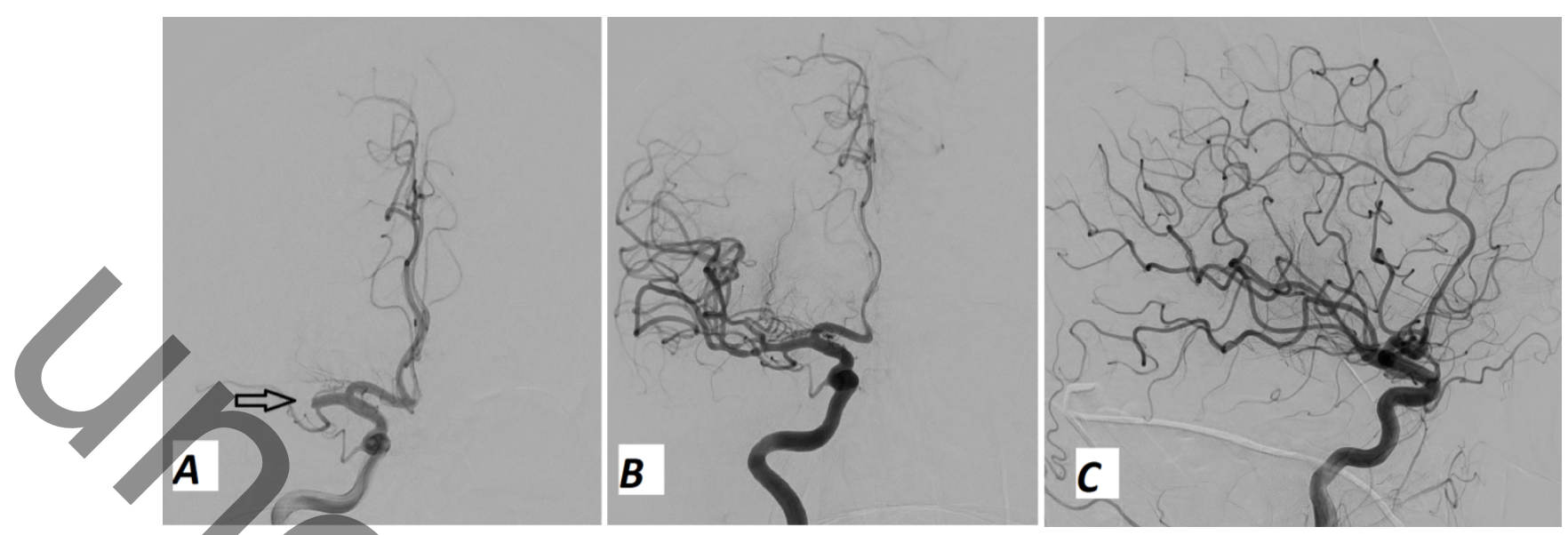

Figure 4: Intracranial selective cerebral anjiographic A:) The right MCA was observed to be occluded after the level where the anterior temporal artery was spared. B) A-P projection and C) Lateral projection; Modified Thrombolysis in Cerebral Infarc

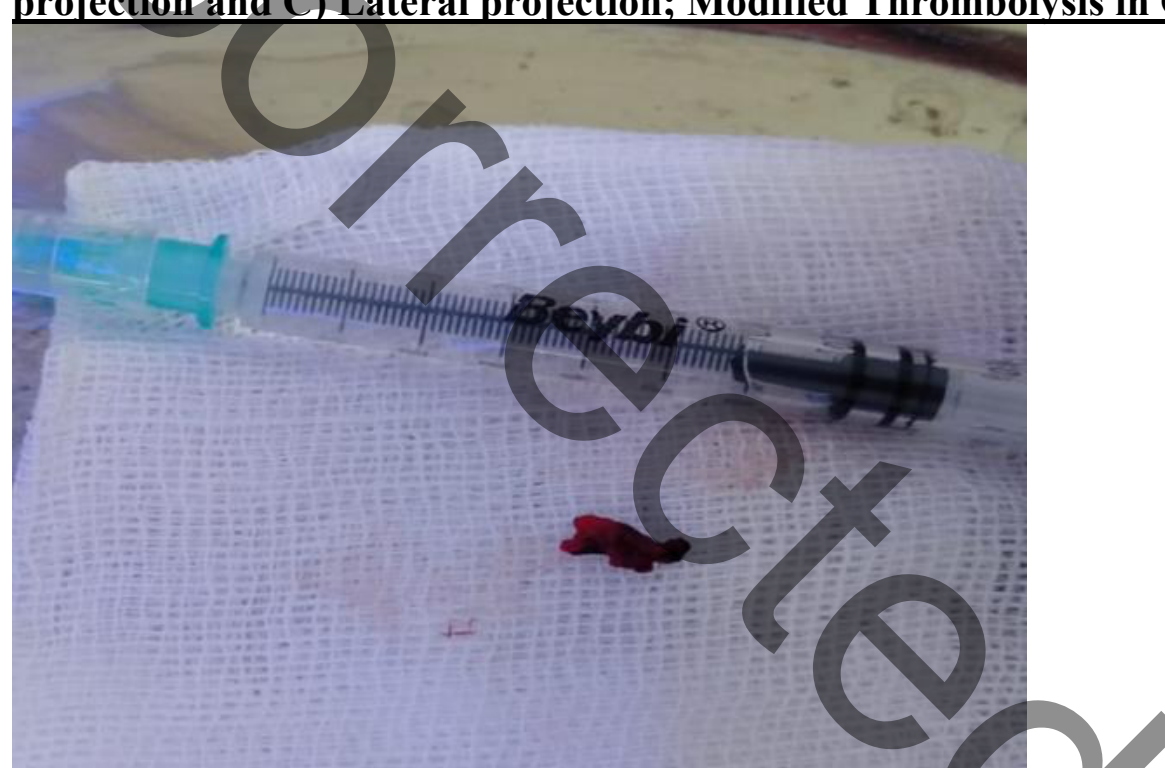

Figure 5: Thrombus specimen retrieved with isolated stent technique as a result of mechanical thrombectomy 


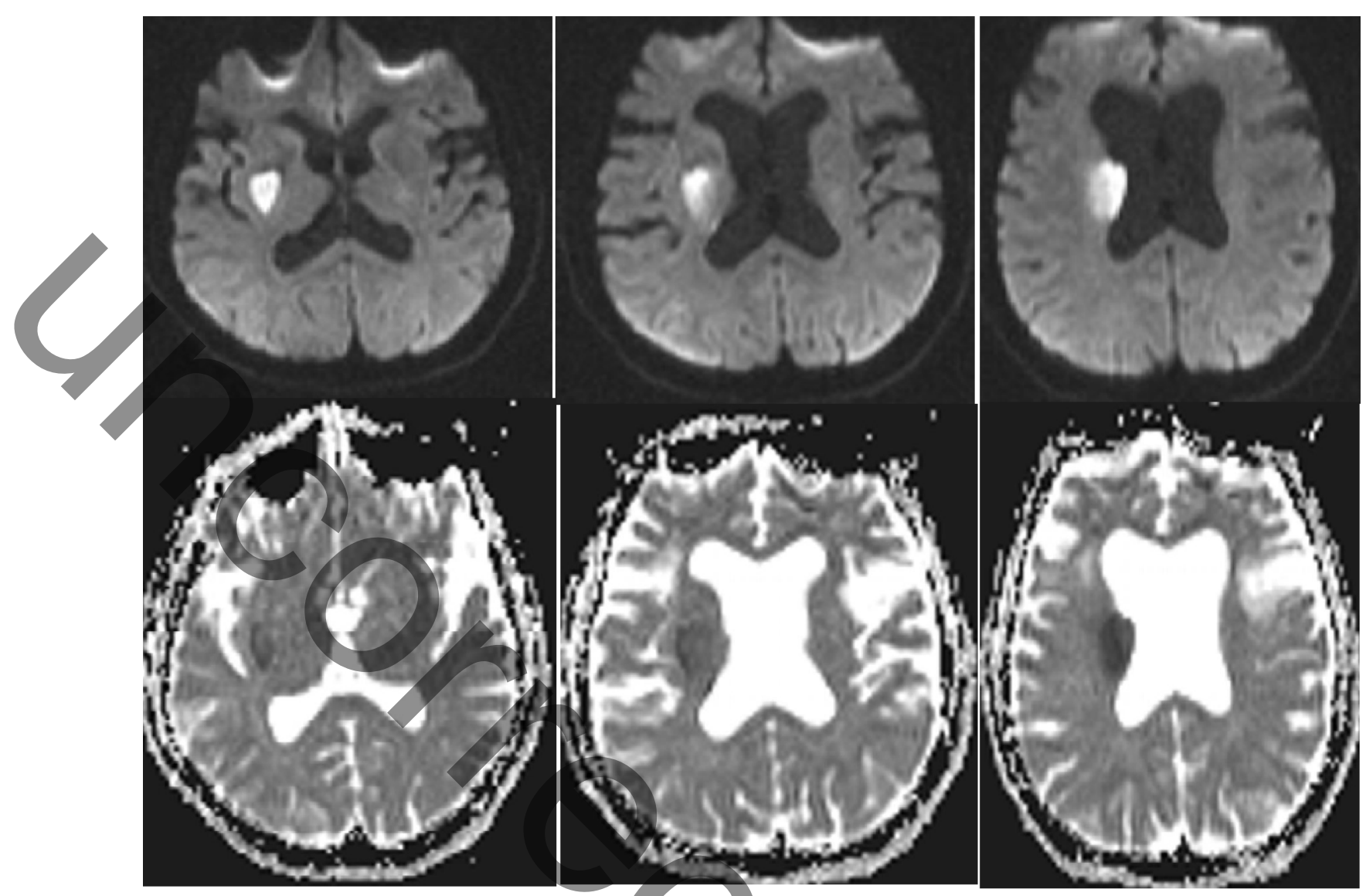

Figure 6: A capsula interna and a corona radiata infarction was observed in DiffusionWeighted Imaging Magnetic Resonance and Apparent diffusion coefficient of the patient

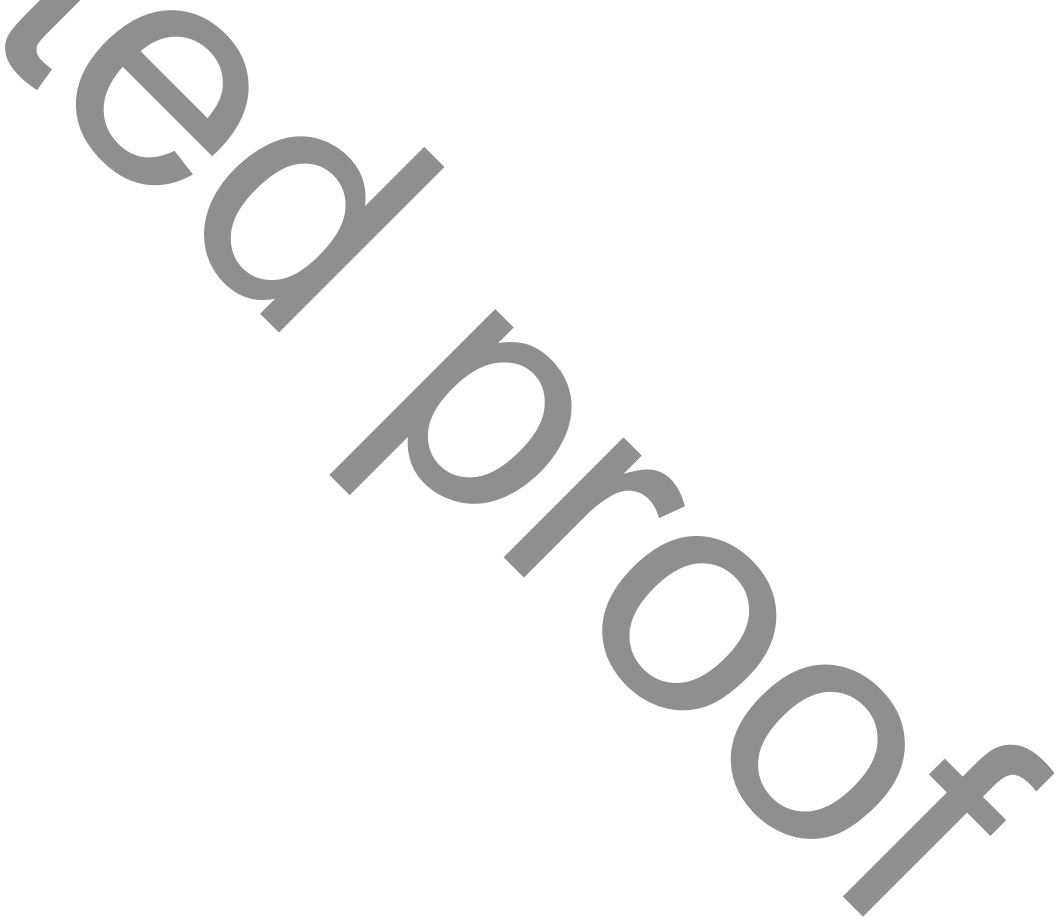

